\title{
Property of Shear Viscosity of Organic Substance Added Surfactant Solution and Effect of Additives on Structural Transformation
}

\author{
Takashi KoshiBA $^{* \dagger}$ and Takehiro YAMAмото** \\ "Department of mechanical Engineering, Nara National College of Technology \\ 22 Yatacho, Yamatokoriyama, Nara, 639-1080, JAPAN \\ ${ }^{* *}$ Graduate School of Engineering, Osaka University \\ 2-1 Yamadaoka, Suita, Osaka, 565-0871, JAPAN
}

\begin{abstract}
We investigated rheological properties of surfactant solutions including a small amount of organic additives, and discussed the effect of additives on the structural transformation of micelles. Test fluids used were mixtures of an aqueous solution of $\mathrm{CTAB} / \mathrm{NaSal}$ and 2,2,4-trimethylpentane (isooctane). The ratio of NaSal to CTAB ( $0.03 \mathrm{~mol} / \mathrm{l})$ was 7.7 and the concentrations of isooctane to the surfactant solution were $0.01 \mathrm{wt} \%$ and $0.1 \mathrm{wt} \%$. In measurements of linear viscoelasticity, it was found that the dynamical property of fluids including additives was described by a single mode Maxwell model. However, the relaxation time decreased with the increase in isooctane concentration. Such change in relaxation time was related to the solubilization of organic additives into micelles, which weakened the mechanical strength of micelles. Furthermore, viscosity curves showed that the structural transformation from a wormlike micelle to a spherical one occurred. In experiments of small angle light scattering in shear flow, the comparison of scattering patterns between a fluid with additives and that without additives captured differences due to the structural transformation. In addition, it was found that the isooctane in solution took a spherical structure, which distributed in a wide range of diameter.

Key Words: Surfactant solution / Organic additive / Structural transformation / Scattering and diffraction pattern / Solubilization
\end{abstract}

\section{有機物質を添加した界面活性剂水溶液のせん断粘度特性と 構造転移に対する添加物の影響}

\author{
小柴 孝 ${ }^{*}$, 山本 剛宏 ${ }^{* *}$ \\ （原稿受理：2012 年 9 月 4 日）
}

\section{1. 緒訔}

カチオン性界面活性剤である臭化セチルトリメチルアン モニウム $(\mathrm{CTAB})$ に塩としてサリチル酸ナトリウム $(\mathrm{NaSal})$ を添加した水溶液では, 界面活性剤および塩濃度の大きさ によりひも状ミセルを形成することが知られている。この ような流体は, 高分子系流体のような粘弾性特性を示すこ とからレオロジー的に関心度が高く，多くの報告がなされ ている. ${ }^{1-5)} こ れ ら の$ 報告では, ひも状ミセル系水溶液の粘弾 性挙動は, ミセル同士の絡み合いによるものであり, 高分 子系流体の鎖状分子の絡み合いと類似しているものの, そ の緩和挙動は塩濃度に依存することから, 高分子系流体と は異なったものであることが示されている. Shikataら ${ }^{2)}$ は, 絡み合ったひも状ミセル系の緩和機構を説明するために「幽 霊網目」モデルを提案し, 添加塩は, ミセルの絡み合い消

$*$ 奈良工業高等専門学校 $\bar{\top}$ 639-1080 大和郡山市矢田町 22

$\dagger$ Tel: +81-743-55-6082, Fax: +81-743-55-6089, E-mail: koshiba@mech.nara-k.ac.jp

** 大阪大学大学院工学研究科 $\bar{\top} 565-0871$ 吹田市山田丘 2 番 1 号
失に対し, 触媒的に作用するとして, その役割を明らかに している。 また, 今井ら ${ }^{6}$ は, 同じく $\mathrm{CTAB}$ 系水溶液に対 し, 添加塩として NapTS ( $p$-トルエンスルホン酸ナトリウム) を用いて, $\mathrm{NaSal}$ の結果と比較し, 塩の違いによるひも状ミ セルの粘弾性挙動への影響を調べている。このように, ひ も状ミセル系水溶液において添加塩が果たす役割は重要で あるが,ささに，塩以外の物質（有機化合物など）を添加 した混合系流体に対して実験がなされている. ${ }^{7-12)}$ 例えば，今 井ら ${ }^{7)}$ は, CTAB/NapTS 系水溶液に芳香族化合物を添加した 混合系のレオロジー特性を調べている。 また, Sreejith ら ${ }^{10)}$ も, $\mathrm{CTAB} / \mathrm{KBr}$ 水溶液に $n$-オクタールを添加し, 添加物濃 度に対するレオロジー特性の変化を明らかにしている。い ずれもミセルの構造転移に関する添加物質の影響を調べる ことを目的とし, その種類や濃度の違いにより興味ある結 果が示されている. 特に, 添加物と界面活性剤との相互作 用，ミセル内への可溶性など，構造転移に影響を及ぼす要 因が挙げられ, 考察されている。ただし, これらの報告では, 添加前のミセルの構造状態として, 多くの場合, 絡み合い をあまり持たないミセル水溶液（短いひも状, あるいは棒状） 
を対象とするものが多く, ひも状構造を有する水溶液に添 加したものは比較的少ない.

そこで, 本研究では, 絡み合ったひも状ミセル水溶液に 有機化合物を少量添加し, そのレオロジー特性を調べること を目的とする。ただ, 有機化合物としては, 添加物と界 面活性剤の相互作用が生じない非芳香族性のものを用いた. 実験は，レオロジー特性として線形粘弾性および定常せん 断特性の測定を行い, 緩和特性について考察する。そして, 流動時の添加化合物の状態を小角光散乱により可視化し, ひ も状ミセルの構造変化について考察を行った。

\section{2. 実験装置および試料流体}

本実験において界面活性剤水溶液に有機化合物を添加し た混合流体のレオロジー特性は, 回転式レオメータにより測 定した. 使用したコーン径は, $43 \mathrm{~mm}$, コーン角は $1 \mathrm{deg}$ である. また, 有機物質を含む界面活性剂水溶液の構造変化を考察 するためにレーザによる小角光散乱実験を行った，実験装 置の概略を Fig. 1 に示す. 2 枚の光学ガラス平板間 $(\phi 50 \mathrm{~mm}$, $\mathrm{Gap}=1.0 \mathrm{~mm}$ ) に封入された試料流体に対し, 上部平板を回 転させ, せん断流動を与える。 このときガラス面に対して垂 直な方向より He-Ne レーザ光 $\left(\lambda_{\text {Laser }}=632.8 \mathrm{~nm}, 10 \mathrm{~mW}\right)$ を照 射し, ミラーを介して平板スクリーンに映し出された散乱 パターンを前方よりビデオカメラを用いて記録する。なお, レーザ光の照射は, 平板外周の影響を受けないように中心 より $21 \mathrm{~mm}$ の位置とした。

界面活性剂水溶液として, 本実験では絡み合ったひも状 ミセルを形成しているとされる濃度比 7.7 の CTAB/NaSal 水 溶液（CTAB：0.03 mol/1, NaSal : $0.231 \mathrm{~mol} / \mathrm{l}$ ）を用いた。溶 媒には，液体クロマトグラフィー用の純水を用いた。 ま た, 添加する有機化合物については, 直鎖状の構造を有し ているとされるイソオクタン（2,2,4-トリメチルペンタン， $\mathrm{CH}_{3} \mathrm{C}\left(\mathrm{CH}_{3}\right)_{2} \mathrm{CH}_{2} \mathrm{CH}\left(\mathrm{CH}_{3}\right) \mathrm{CH}_{3}$, 分子量 114.23）を用い, その濃 度は, $0.01 \mathrm{wt} \%$ と $0.1 \mathrm{wt} \%$ の 2 種類とした. なお, 試料流体 としては, 界面活性剤水溶液にイソオクタンを混入後, 十 分攪拌したものを使用した。

\section{3. 実験結果・考察}

\section{1 せん断流動特性}

試料流体のレオロジー特性として, まず, 動的粘弾性率 の測定を行った. Fig. 2 にその結果を示す. 貯蔵弾性率 $G^{\prime}$ お よび損失弾性率 $G^{\prime \prime}$ のいずれもイソオクタン濃度が高くなる と高周波数域に移動する傾向となる。ただ, その特性は, 単一緩和モードの Maxwell モデルでフィッティングすること ができ, この範囲のイソオクタン濃度では, 絡み合ったひ も状構造を維持していると考えられる. Table I にフィッティ ングにより得られた平坦剛性率 $G_{N}^{0}$, ならびに緩和時間 $\lambda$ の 值を示す.

その結果, $G_{N}^{0} に$ 比べ, $\lambda$ の值はイソオクタン濃度の増加 に対し, 顕著に減少することがわかる。このような結果は, 今井ら ${ }^{7)}$ の報告とよく似ている. 彼らは, 長いひも状ミセル 水溶液にスチレン（St）やトルエン（Tol）などの有機化合 物を少量添加し, 動的粘弾性を調べた。 そして, 緩和時間 が短くなるのは, 有機化合物がミセル構造に影響を与えな
いミセル深部の疎水的な部分に可溶化したことでミセルの 強度が弱まったためと考察している。このことから，本実 験においても， CTAB/NaSal 系水溶液に添加したイソオク夕 ンは, ミセルの疎水部に可溶化されていると考えられる.

つぎに，定常せん断粘度特性を Fig. 3 に示す．いずれの流 体もせん断速度 $\dot{\gamma}$ の増加に対し, せん断粘度の shear-thinning 性が確認できる。しかしながら, その様子を詳しく見るとイ ソオクタンの添加により特性に違いが見られる。すなわち, 濃度 $0.01 \mathrm{wt} \%$ の粘度曲線は, 濃度 $0 \mathrm{wt} \%$ の結果（界面活性 剂水溶液のみ）と交差するような挙動を示している。その 様子は, せん断応力で表示すると, より顕著に現れている. 一方, $0.1 \mathrm{wt} \%$ の場合, $\dot{\gamma}<2.0 \mathrm{~s}^{-1}$ では, $0.01 \mathrm{wt} \%$ とほぼ同じ 值であるが, $\dot{\gamma}>2.0 \mathrm{~s}^{-1}$ になると，ほかの流体に比べて粘度 の值は小さくなっている. また, $\dot{\gamma}=2.0 \mathrm{~s}^{-1}$ 近くでは, せん 断応力の変化はせん断速度に対し平坦となっている.

ひも状ミセル系水溶液と有機化合物の混合流体の定常せ ん断粘度は, Molchanov ら ${ }^{11)}$ の報告においても示されている. 彼らは, 界面活性剂水溶液中において有機物質が飽和状態,

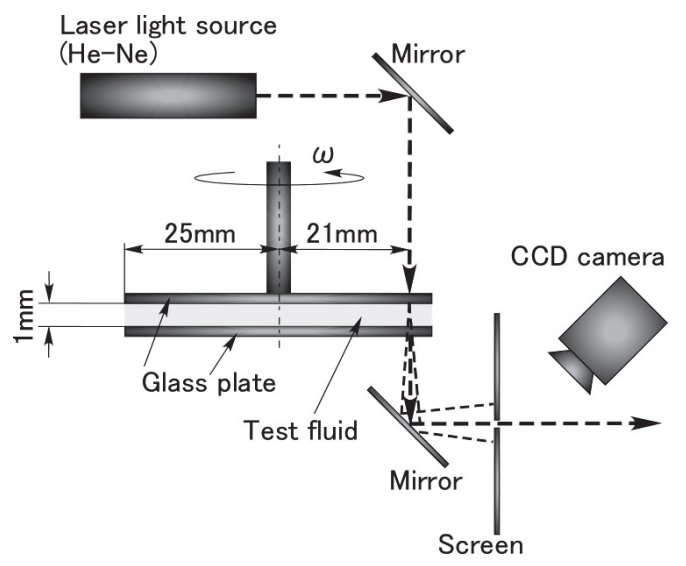

Fig. 1. Schematic view of experimental apparatus.

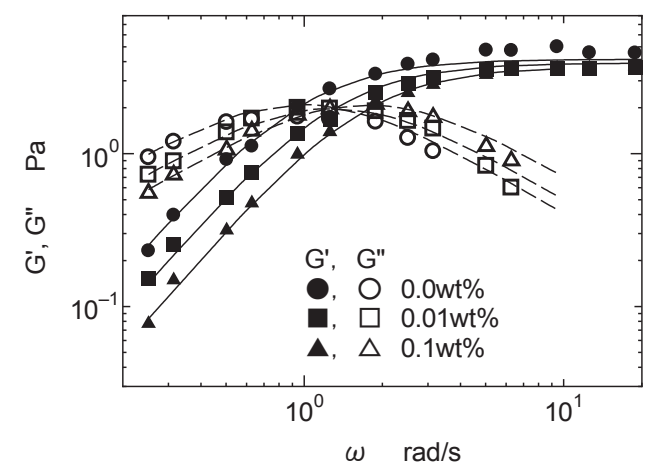

Fig. 2. Storage and loss moduli for test fluids.

Table I. Plateau modulus $G_{0}$ and relaxation time $\lambda$.

\begin{tabular}{|c|c|c|}
\hline Isooctane conc. wt\% & $G_{N}^{0} \mathrm{~Pa}$ & $\lambda \mathrm{s}$ \\
\hline 0 & 4.15 & 1.01 \\
\hline 0.01 & 3.92 & 0.77 \\
\hline 0.1 & 3.85 & 0.57 \\
\hline
\end{tabular}


すなわち溶け込んだ状態の流体を用いて, せん断粘度を測 定した。その結果, 添加前では shear-thinning 性を示してい た流体が, 添加後は, ニュートン流体のような一定の粘度 特性に変化することを示した。 そして, その原因として添 加物の可溶化によるミセルの膨潤ならびに構造転移（ひも 状から多数の球状へ変化) を挙げ, さらに, 小角中性子散 乱（SANS）実験から可溶化の根拠を示している．本実験の 場合, $\mathrm{CTAB} / \mathrm{NaSal}$ 水溶液に添加したイソオクタンは, 少量 であることから，飽和状態とは言えず，Molchanovらのよう な顕著な粘度の変化は見られないが, Fig. 2 にも示したよう に, ミセル内にイソオクタンが可溶化されたことでミセル 強度が低下し，構造变化が起きやすくなると予想される。ま

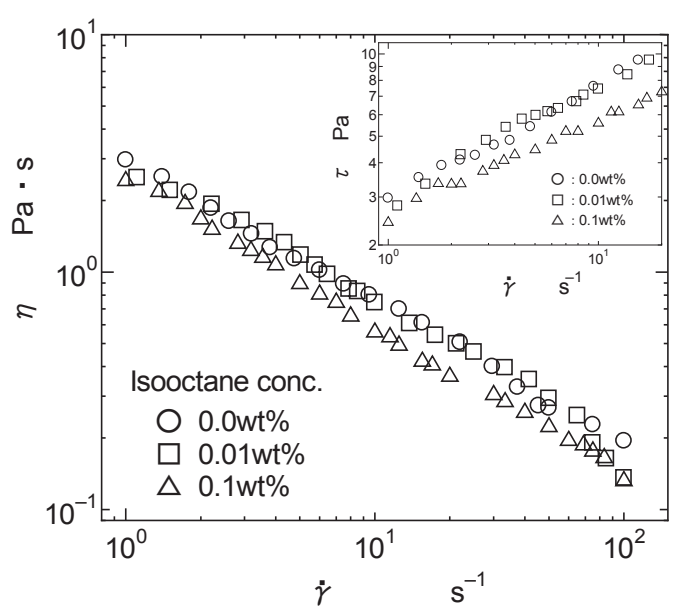

Fig.3. Steady shear viscosity for test fluids. Inset graph shows the details of shear stress property.

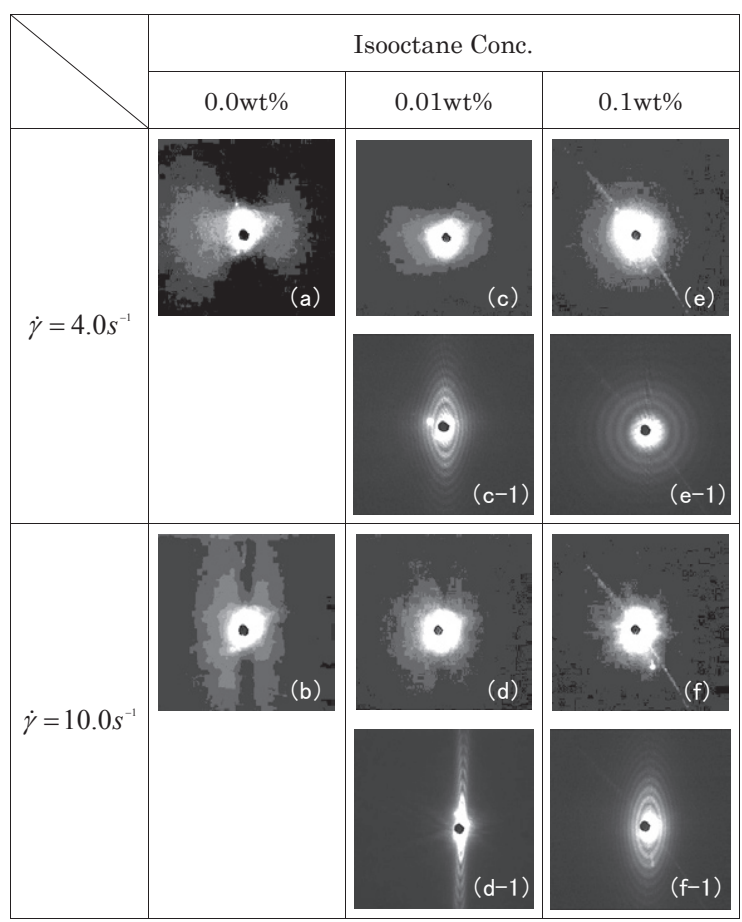

Fig. 4. Scattering or diffraction patterns in a shear flow for test fluids.
た, ひも状ミセル系水溶液の shear-thinning 挙動は, 流れ方 向へのミセルの配向によるものとされ，さらに，高せん断 速度域ではミセルの断裂やミセル同士の絡み合い消失など の流動による構造変化が生じ, 粘度特性にもその影響が現 れるとされている。本実験で使用した界面活性剤濃度の場 合, shear-thinning 性を示すものの高せん断速度域における構 造変化は，あまり顕著に現れないとされているが, Fig. 3 の 濃度 $0 \mathrm{wt} \%$ では, $\dot{\gamma}=50 \mathrm{~s}^{-1}$ 近くで, わずかに粘度曲線の勾配 が緩やかになり,構造変化を示唆する挙動が見られる。また, $0.01 \mathrm{wt} \%$ 濃度では, その挙動が $\dot{\gamma}>30 \mathrm{~s}^{-1}$ で現れている. 一方, $0.1 \mathrm{wt} \%$ では, $\dot{\gamma}=20 \mathrm{~s}^{-1}$ あたりでわずかに勾配の変化が見ら れるが，この場合， $\dot{\gamma}=2.0 \mathrm{~s}^{-1}$ でも粘度の変化が生じている. このように，イソオクタンの添加は，流動による構造変化 に影響を与えるものであるが，そこには，ミセル強度の低下， あるいは，構造転移が関与するものと推測される.

\section{2 光散乱パターン}

Fig. 4 に流動時における光散乱パターンを示す．流動方向 は左向きであり, 各パターンの中央部にある黒点は, スク リーンに設けた穴であり, 強度の強いビームはこの穴を通過 する．また，いずれの画像も微弱な強度変化を示すために 色調補正を行っている。 なお, 界面活性剂水溶液のみの場合, 流動開始より約 50 秒以上経過したパターンであるが，イソ オクタンを添加した場合, 散乱パターンの時間変化が激し かったため，ここでは代表的なパターンのみを示している。

Fig. 4 より，イソオクタン濃度 $0 \mathrm{wt} \%$, 女ん断速度 $\dot{\gamma}=4.0 \mathrm{~s}^{-1}$ における散乱パターンは, 流れと平行な方向に光強 度の高い領域が分布するバタフライ形状となり, $\dot{\gamma}=10.0 \mathrm{~s}^{-1}$ では，流れと垂直な方向に光強度の低い箇所が筋状となるパ ターンに変化している. 一方, イソオクタンを添加した場合, 散乱パターンに変化が生じている．濃度 0.01 wt\%（Fig. 4 (c), (d)）では，バタフライパターンはわずかに見られるが，そ の様子はあまり顕著ではない.また，0.1 wt\%（Fig. 4 (e), (f))

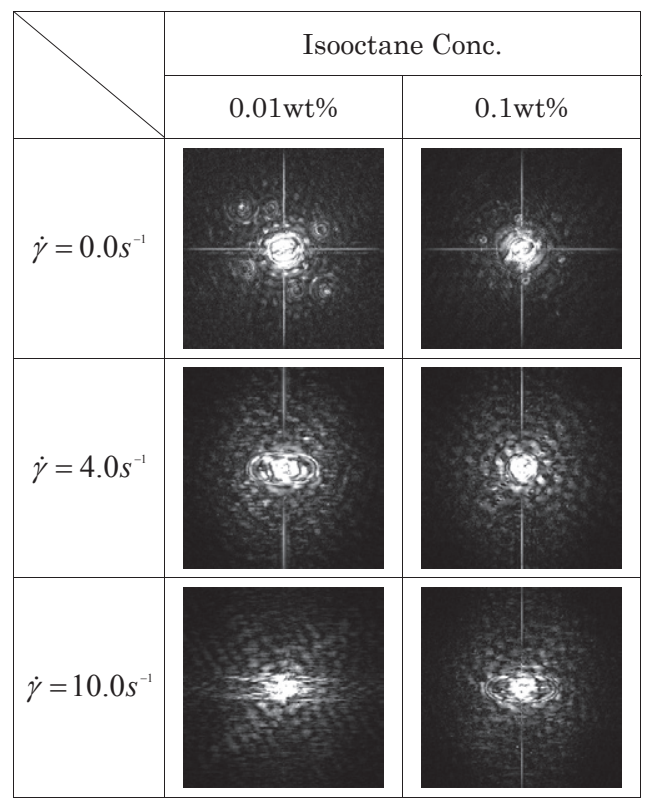

Fig. 5. Objective images obtained from diffraction patterns by a phase retrieval method. 
では，流動中にバタフライパターンは確認できず，階調変 化はビーム中央から放射状に広がっている. Kadoma ら 13-14) は, ひも状ミセル水溶液の小角光散乱実験を行い, バタフ ライ状の散乱パターンの発生は, 溶媒中のミセルの濃度変 動, ならびに流動による構造変化によるものと考察してい る. 濃度 $0 \mathrm{wt} \%$ の場合は, Kadoma らの考察に従うと考えら れるが，イソオクタンを添加した場合は，明らかに異なっ た散乱パターンを示していることから，前項で述べたよう に絡み合ったひも状構造が構造転移を起こしていると考え られる。なお，イソオクタンを含む場合，Fig. 4(c)〜 (f)の 散乱パターンの他に Fig. 4 (c-1)〜 (f-1)のような縞模様が流 動中，断続的に観察されたが，これは，光の回折によるも のと考えられる。ただし，回折縞が生じるためには，光の 波長程度の大きさの液滴が必要となる。そこで, 回折縞の 発生条件 ${ }^{15)}$ より液滴の大きさを見積もったところ, 本実験 の場合，液滴径は $2 \mu \mathrm{m}$ 以上であると予想された。この值は， 数 $\mathrm{nm}$ のオーダーとされるミセル直径と比べて非常に大き く, また, 可溶化によるミセルの膨潤から考えても, それ以 上の大きさとなる。しかしながら, 回折縞の発生状況から 液滴は局所的に存在し, 回折縞が生じない場合は, Fig. 4(c) 〜 (f) の散乱パターンを示したことから, 流体中, イソオク タンの多くは, 可溶化されていると考えられる. なお, 液 滴の存在については, 二つの可能性が考えられる。ひとつは, 液滴の状態で流体中に溶け达んでいる場合と，もう一つは， 可溶化により膨潤したミセルが流動により回折可能な状態 (凝集·合一など) となった場合である。前者に関しては, レー ザ光の入射位置にもよるが静置状態でも回折縞が確認され たことより, その可能性は高いと思われる。, 一方，後者は， 可能性としては十分考えられるが, 本実験ではその詳細を 示すまでには至らなかった。 なお, Fig. 4 に示す回折パター ンは, せん断速度の増加とともにその形状が変化している ことから, その挙動を調べることは, 液滴の存在形態を知 ることに繋がると考えられる。そこで, 本実験では, 回折 パターンからフーリエ反復法 ${ }^{17-18)}$ を用いて位相情報を回復 させ, 流動中の液滴の様子を調べた.

Fig. 5 にその結果を示す。なお, この場合, Fig. 4 と同様, 流れ方向は左向きである. 静止状態 $\dot{\gamma}=0 \mathrm{~s}^{-1}$ の場合, 回折パ ターンは Fig. 4(e-1)のような同心の円環縞であったことか ら, 位相回復した画像は, いずれの濃度においても中央に 明るい円を示しており, 水溶液中の液滴は, ほほ球状であ ると言える。なお, この場合, 中央部から少し離れた箇所 において, 小さな液滴がいくつか存在していることが確認 できる。一方, せん断速度が増加すると, 濃度 $0.01 \mathrm{wt} \%$ で は, 球形の液滴が流れ方向に対し長軸を持つ楕円体に変形 し, $\dot{\gamma}=10.0 \mathrm{~s}^{-1}$ では, その様子が顕著なものとなっている. また, 濃度 $0.1 \mathrm{wt} \%$ の場合, $\dot{\gamma}=4.0 \mathrm{~s}^{-1}$ のときは形状に大きな 変化は見られないが, $\dot{\gamma}=10.0 \mathrm{~s}^{-1}$ では, 液滴は, 流れ方向に 対し，楕円状に変形している様子がわかる.

以上のことから，水溶液中の液滴は，形状を安定にした 状態，すなわち界面活性剂分子が液滴の周囲を取り囲むよう にして存在していると考えられる。ただし,この場合, 水溶 液の構造が絡み合ったひも状であり, さらにミセル径に比 べて液滴径が大きいことから, 液滴の存在は, ミセル内部 よりミセル表面に付着しているのではないかと推測される. なお, 流動中, 液滴はせん断変形を受けるが, せん断速度
が大きくなると, 液滴の分裂が予想され, 分裂した液滴は, 膨潤したミセルとして水溶液中に存在するものと思われる.

\section{4. 結 言}

絡み合ったひも状ミセル構造を有する $\mathrm{CTAB} / \mathrm{NaSal}$ 水溶液 に有機物質としてイソオクタンを少量添加し, そのレオロ ジー特性を調べた。その結果，イソオクタンを添加した場合 でも, CTAB/NaSal 水溶液の線形粘弾性は, 単一緩和モード の Maxwell モデルに従うことがわかった。しかしながら，イ ソオクタン濃度の増加とともに緩和時間は, 短くなり, ミセ ル内にイソオクタンが可溶化していることを示した。一方, 定常せん断粘度特性では，也ん断速度の増加とともに流動 による構造変化を示す挙動が確認され，そのときのせん断 速度は, イソオクタン濃度の増加に対し, 低くなる傾向を 示した。 これは, イソオクタン添加によるミセル強度の低 下，そしてひも状から，一部，球状へと構造転移している ことを示唆するもので, その様子は, 小角光散乱の実験に おいて確認された。 なお，イソオクタンが可溶化したミセ ルの大きさは, 幅広い径分布を有しており, それは, 流動中, 散乱パターンの変化として現れた

\section{REFERENCES}

1) Shikata T, Hirata H, Langmuir, 3, 1081 (1987).

2) Shikata T, Hirata H, Langmuir, 4, 354 (1988).

3) Shikata T, Hirata H, Langmuir, 5, 398 (1989).

4) Inoue $T$, Inoue $Y$, Watanabe $H$, Langmuir, 21, 1201 (2005).

5) Takagi A, Sasaki H, Kuriyama A, Matsumiya Y, Inoue T, Watanabe H, Nihon Reoroji Gakkaishi, 34, 165 (2006).

6) Imai S, Kunimoto E, Shikata T, Nihon Reoroji Gakkaishi, 28, 61 (2000).

7) Imai S, Kunimoto E, Shikata T, Nihon Reoroji Gakkaishi, 28, 67 (2000).

8) Brackman JC, Engberts JBFN, J Am Chem Soc, 112, 872, (1990).

9) Kandori K, McGreevy RJ, Schechter RS, J Phys Chem, 93, 1506 (1989).

10) Sreejith L, Parathakkat S, Nair SM, Kumar S, Varman G, Hassan PA, Talmon Y, J Phys Chem B, 115, 464 (2011).

11) Molchanov VS, Philippova OE, Khokhlov AR, Langmuir, 23, 105 (2007).

12) Siriwatwechakul W, LaFleur T, Prud'homme RK, Sullivan $P$, Langmuir, 20, 8970 (2004).

13) Kadoma IA, Egmond JW, Phys Rev Lett, 77, 4432 (1996).

14) Kadoma IA, Ylitalo C, Egmond JW, Rheol Acta, 36, 1 (1997).

15) Funtaikougakkai, “Funtai no Kisobussei Vol.1” (2011), Nikkankougyousinbunsya, p25.

16) Rothstein JP, J Rheol, 47, 1227 (2003).

17) Marchesini S, He H, Chapman HN, Hau-Riege SP, Noy A, Howells MR, Weierstall U, Spence JCH, Phys Rev B, 68, 140101 (2003)

18) Watanabe M, Shioya H, Gohara K, IEICE Technical Report, NC2006-89, 7 (2007). 